\title{
PERAN IMUNOGLOBULIN A (SIgA) DALAM MENGHAMBAT PEMBENTUKAN BIOFILM STREPTOKOKUS MUTANS PADA PERMUKAAN GIGI
}

\author{
(ROLE OF IMMUNOGLOBULIN A (SIgA) IN INHIBITING BIOFILM FORMATION \\ OF STREPTOCOCCUS MUTANS ON THE TOOTH SURFACES)
}

\author{
Maulida Hayati, Herry Herman, Andri Rezano \\ Pascasarjana Program Magister Ilmu Kedokteran Dasar (Oral Biologi) \\ Fakultas Kedokteran Universitas Padjadjaran \\ Jl. Prof. Eyckman No. 38 Bandung 40161 \\ E-mail: maulidahayati81@gmail.com
}

\begin{abstract}
Secretory $\operatorname{Ig} \mathrm{A}(\mathrm{SIg} \mathrm{A})$ is an antibody class presents in the saliva. It is formed as dimeric IgA by local plasma cells (PCs) in the stroma of salivary glands and subsequently transported through secretory epithelia by the polymeric Ig receptor (pIgR), otherwise called membrane secretory component (SC). On the mucosal surface, SIgA antibodies together with mucous performed immune exclusion of antigen. The article was to determine the role of SIgA in improving oral mucosal defense against pathogenic bacteria Streptococcus mutans. These bacteria are the major etiology of dental caries, through its ability to adhere to a solid surface. Adhesion allows colonization of the tooth surface through the formation of the protective biofilm. Adhesion is inhibited by SIgA by interfering with bacterial adhesion protein called $\mathrm{Ag}$ I/II. This ability allow SIgA to prevent adhesion, hence, prevent the initiation of carries. In conclusion, secretory of SIgA saliva to Ag I/II of Streptococcus mutans has shown to be able to prevent colonization in human oral cavity.
\end{abstract}

Key words: antigen I/II, Streptococcus mutans, secretory IgA (SIgA)

\begin{abstract}
Abstrak
Sekretori $\operatorname{IgA}$ (SIgA) adalah salah satu kelas andibodi yang terdapat dalam saliva, yang dihasilkan dalam bentuk dimerik IgA oleh sel plasma lokal (PCs) pada stroma glandula saliva dan kemudian ditransportasi melalui epitel sekretori oleh polimer Ig reseptor (pIgR), yang disebut juga dengan membran komponen sekretori (SC). Pada permukaan mukosa SIgA bersama dengan mukus akan mengekslusi antigen-antigen. Tujuan penulisan artikel ini adalah untuk menjelaskan peran SIgA dalam meningkatkan pertahanan mukosa mulut terhadap bakteri patogen Streptokokus mutans. Bakteri ini merupakan penyebab utama terjadinya karies gigi, karena kemampuannya untuk melekat pada permukaan gigi, yang memungkinkan terbentuknya kolonisasi pada permukaan gigi melalui pembentukan biofilm. Perlekatan Streptokokus mutans ini akan dihambat oleh SIgA dengan mengintervensi protein perlekatan bakteri yang disebut Ag I/II. Hal ini memungkinkan SIgA untuk mencegah perlekatan bakteri pada permukaan, sehingga dapat mencegah inisiasi terjadinya karies gigi. Sebagai kesimpulan, sekresi SIgA saliva terhadap Ag I/II Streptokokus mutans telah terbukti dapat mencegah kolonisasi bakteri tersebut di rongga mulut manusia.
\end{abstract}

Kata kunci: antigen I/II, Streptokokus mutans, sekretori IgA (SIgA)

\section{PENDAHULUAN}

Masalah kesehatan gigi dan mulut terutama karies gigi di Indonesia masih memiliki angka prevalensi yang tinggi, hal ini dapat dilihat dari data RISKESDAS (Riset Kesehatan Dasar) tahun 2013, yang menyatakan bahwa prevalensi karies tertinggi terjadi pada usia produktif. Pada usia 35-44 tahun terdapat prevalensi karies sebesar $30,5 \%$ dan pada usia 45-54 tahun sebesar 31,9\%. ${ }^{1}$

Karies gigi pada manusia merupakan penyakit infeksi yang menyerang jaringan keras rongga mulut yaitu gigi, yang melibatkan bakteri. Streptokokus mutans adalah salah satu bakteri patogen rongga mulut yang merupakan agen etiologi utama karies gigi. ${ }^{2}$ Bakteri ini telah disepakati sebagai agen utama etiologi karies gigi pada manusia dan binatang coba, karena bakteri ini ditemukan pada populasi yang 
mempunyai prevalensi karies tinggi, rendah dan paling rendah. Di antara serotipe S. mutans yang ada, serotipe $\mathrm{c}$ predominan ditemukan pada biofilm (plak) dan saliva. Bakteri ini secara struktural dan antigenetikal mengekpresikan protein permukaan yang disebut antigen I/II yang mempunyai berat molekul $185 \mathrm{kDa}^{3}$ Antigen ini oleh para peneliti dinyatakan berperan dalam patogenesis karies gigi, dan efektif sebagai vaksin dalam pencegahan karies gigi. Antigen I/II S. mutans ini mempunyai sifat ade-sif, pada saat bakteri tersebut melekat pada kom-ponen inangnya selama berkolonisasi dan infeksi. Antigen protein permukaan ini berpengaruh dalam perlekatan S. mutans dengan acquired pellicles pada permukaan gigi. ${ }^{3-6}$

Antibodi dalam sistem imun lokal maupun sistemik terhadap S. mutans ikut berperan dalam proteksi terhadap karies gigi. Sistem imun saliva lokal diperankan oleh sekretori IgA (SIgA). Sekretori IgA (SIgA) saliva dapat berikatan secara spesifik dengan epitop dari bagian antigen I/II S. mutans, sehingga bakteri tidak dapat berikatan dengan pelikel saliva dan S. mutans tidak akan berkolonisasi pada permukaan gigi. ${ }^{3,4,67-9}$ Penulisan artikel ini bertujuan untuk mengetahui peran SIgA dalam meningkatkan pertahanan mukosa mulut terhadap bakteri patogen Streptococcus mutans.

\section{STREPTOCOCCUS MUTANS}

Streptococcus mutans merupakan bakteri yang berperan penting dalam proses terjadinya karies gigi. Bakteri ini pertama kali ditemukan oleh Clark pada tahun 1924 yang berbentuk kokus dengan formasi rantai panjang apabila ditanam pada media Brain Heart Infusion (BHI) Broth dan pada media agar akan mempelihatkan rantai pendek dengan bentuk sel tidak beraturan. S. mutans adalah bakteri Gram positif, tidak bergerak, diameter 0,5-2 $\mu \mathrm{m}$. Bakteri ini membentuk koloni seperti bunga kol, sangat lengket dan berbau khas seperti bau karamel, tersusun seperti rantai dan tidak membentuk spora serta mempunyai delapan serotipe. S. mutans tumbuh dalam suasana fakultatif anaerob, termasuk ke dalam kelompok $S$. viridans yang merupakan flora normal rongga mulut yang memiliki sifat $\alpha$-hemolitik dan komensal oportunistik. Bakteri akan tumbuh secara optimal pada suhu sekitar $18^{0}-40^{\circ} \mathrm{C}$, pada $\mathrm{pH}$ 5,2-7. ${ }^{10}$

FAKTOR VIRULENSI STREPTOCOCCUS MUTANS

Glucosyltransferase yang dihasilkan oleh $S$. mutans terdiri atas GtfB, GtfC, dan GtfD. Glucosyl- transferase berperan penting dalam pembentukan biofilm plak gigi dan bertanggung jawab untuk pembentukan glukan dari sukrosa. Sintesis glukan memungkinkan terjadinya perlekatan bakteri pada permukaan email gigi dan perlekatan dengan bakteri lain. Dengan adanya proses ini, akan terbentuk mikrokoloni-mikrokoloni yang akan mendukung terbentuknya biofilm. Masing-masing dari tiga jenis Gtf memiliki fungsi yang berbeda, meskipun memiliki peran yang sama dalam pembentukan biofilm. $2,4,6$

Dalam penelitian terdahulu pernah dilaporkan bahwa $G t f$ sangat cepat diabsorbsi (sekitar 1 menit) ke permukaan hidroksiapatit (sHA) email yang dilapisi pelikel saliva. GtfC dilaporkan memiliki afinitas tertinggi terhadap sHA, Glucosyltransferase jenis ini merupakan senyawa hidrofilik dan menghasilkan suatu campuran yang larut (sebagian besar ikatan $\alpha-1,6)$ dan glukan yang tidak larut. Namun, Glucosyltransferase ini memiliki domain hidrofobik yang dihubungkan dengan afinitasnya untuk biofilm plak gigi. Hal ini memungkinkan interaksi dengan protein saliva dalam pelikel seperti lisozim dan $\alpha$ amilase. GtfB adalah jenis Glucosyltransferase yang berperan dalam interaksi S. mutans dengan bakteri lain terutama dalam mensintesis glukan yang tidak larut yang sebagian besar memiliki ikatan $\alpha-1,3$. Gtf ini bertanggung jawab untuk diferensiasi mikrokoloni yang membentuk struktur biofilm. ${ }^{11}$ Di samping itu, GtfD sebagian besar terdapat dalam bentuk larutan, mempercepat metabolisme polisakrida dan berperan sebagai primer untuk $G t f B{ }^{2,6}$

Glucosyltransferase juga mampu berikatan dengan sel-sel bakteri lain, oleh karena itu, kerjasama antara Gtf dan mikroorganisme memungkinkan untuk membangun sebuah plat yang sangat melekat pada permukaan gigi dengan ikatan yang stabil antara sel-sel bakteri (Gambar 1). ${ }^{6}$

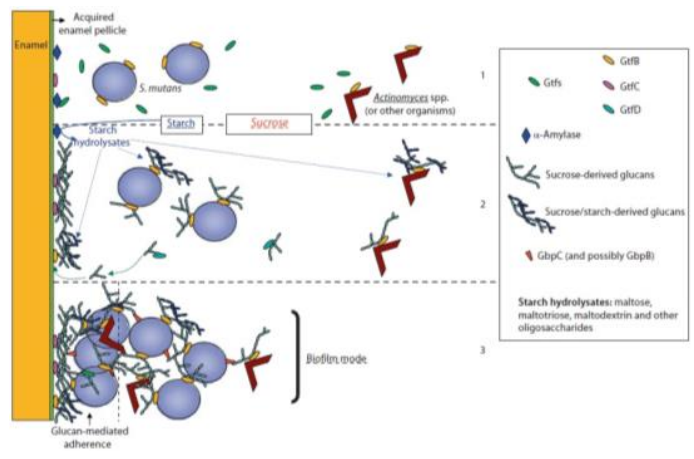

Gambar 1. Perkembangan pembentukan biofilm plak yang dimediasi oleh Gtf S. mutans ${ }^{2}$

Glucans binding of proteins (Gbp) merupakan komponen virulen $\mathrm{S}$. mutans yang berperan dalam 
mediasi mengikatkan bakteri pada glukan. Terdapat empat jenis protein $G b p$ yaitu, $G b p A, G b p B, G b p C$, $G b p D$. $G b p C$ dan $G b p B$. Dikaitkan dengan dinding sel bakteri mereka bertindak sebagai reseptor khusus untuk gukan. Keempat jenis $G b p$ ini berperan dalam perlekatan bakteri dan pembentukan biofilm (Gambar 2). ${ }^{4,6}$

Protein permukaan yang dimiliki oleh S. mutans adalah antigen I/II (Ag I/II). Famili protein ini direpresentasikan oleh $S p a P, S s p A$ atau $S s p B$ yang terdapat pada permukaan S. mutans (Gambar 2). ${ }^{3-5,9}$

Selain itu, Streptococcus mutans dapat memproduksi asam dari substrat karbohidrat (glukosa dan fruktosa) yang dikenal dengan sifat asidogenik. Di samping itu sifat asidurik, memungkinkan bakteri ini dapat bertahan dalam kondisi $\mathrm{pH}$ rendah $(\mathrm{pH}$ 3,0 ) yang menyebabkan demineralisasi pada email, sehingga meningkatkan potensi kariogenik. ${ }^{6,12}$

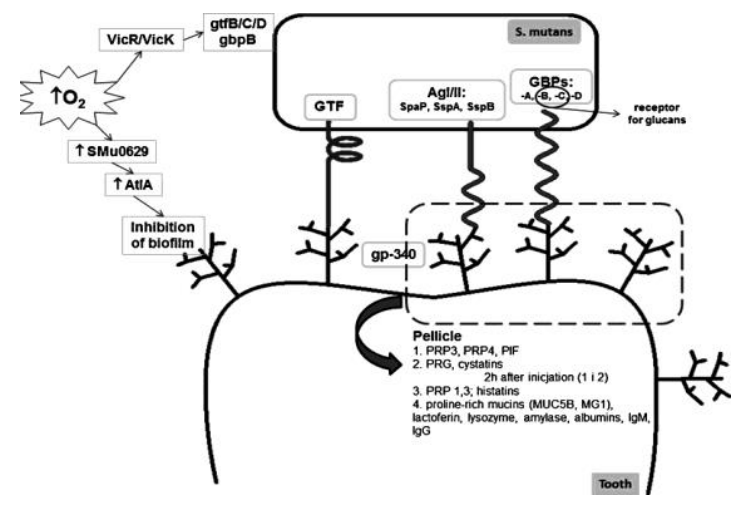

Gambar 2. Peran S. mutans dalam proses pembentukan biofilm pada permukaan gigi ${ }^{6}$

\section{BIOFILM}

Kolonisasi dan akumulasi S. mutans dipengaruhi oleh berbagai faktor di rongga mulut, seperti nutrisi, kebersihan rongga mulut, komponen saliva, daya alir saliva dan karakteristik-karakteristik yang berkaitan dengan faktor virulensi bakteri. ${ }^{13}$ Biofilm (plak gigi) adalah kumpulan atau agregasi bakteri, ganggang, jamur dan protozoa yang tertutup matriks berisi campuran senyawa polimer terutama polisakarida yang melekat pada permukaan gigi. Plak terdiri atas air (80\%), glukan (10-20\%), fruktan (1-2\%) dan protein (40\%). Selain itu, juga terdapat substansi polimer polisakarida ekstraseluler (EPS) yang terdiri atas partikel organik, partikel anorganik, mikroorganisme dan partikel yang larut dalam air., ${ }^{2,6}$

Tahap pertama pembentukan plak adalah perlekatan pelikel saliva pada permukaan email gigi (Aquired Enamel PelliclelAEP). Pelikel saliva terbentuk dari komponen-komponen saliva seperti prolin kaya protein, amilase, lisozim, histatin, peroksidase, musin dan komponen bakteri yang meliputi fruktantransferase, glukosiltransferase dan asam lipoteichoic. Pelikel berfungsi sebagai lapisan pelindung, pelicin permukaan, mencegah kerusakan jaringan dan tempat perlekatan bakteri. Pelikel akan terbentuk segera setelah penyikatan gigi. ${ }^{2,6}$

Tahap kedua pembentukan plak gigi, terjadi kolonisasi bakteri (mikrokoloni). Bakteri awal yang melekat dan berkoloni adalah bakteri Gram positif. Koloni ini awalnya bersifat reversibel, kemudian akan berubah jadi ireversibel. ${ }^{2,6}$

Tahap ketiga pembentukan plak adalah terjadi pertumbuhan koloni Gram positif, disertai agregasi bakteri lain sehingga terjadi kolonisasi sekunder, kemudian terjadi peningkatan jumlah dan spesies bakteri. Dalam tahap ini terjadi perubahan lingkungan, dari aerob menjadi anaerob yang didominasi oleh bakteri Gram negatif. Pematangan plak merupakan proses akhir terbentuknya plak, umumnya terjadi dua hari setelah plak terbentuk. ${ }^{2,6}$

\section{SEKRETORI IMMUNOGLOBULIN A (SIgA)}

Imunoglobulin A ( $\operatorname{Ig} \mathrm{A})$ merupakan antibodi yang berperan penting dalam imunitas mukosa. IgA memiliki dua subkelas yaitu IgA1 dan IgA2, dalam bentuk dimer yang disebut juga dengan IgA sekretori (SIgA). IgA1 merupakan subkelas IgA yang dominan ditemukan dalam serum (80\%), sementara IgA2 lebih banyak ditemukan dalam sekresi eksternal seperti kolostrum, air mata dan saliva (20\%). Komponen SIgA melindungi imunoglobulin dari degradasi enzim proteolitik, sehingga SIgA dapat memberikan pertahanan tubuh terhadap bakteri patogen. Selain itu SIgA juga dapat menghambat efek inflamasi. ${ }^{14,15,16}$

Dua kelas antibodi utama yang ada dalam saliva yaitu IgA (SIgA) dan IgG, diproduksi sebagai dimer IgA oleh sel plasma lokal di dalam stroma kelenjar saliva. Kemudian antibodi ini dibawa melalui epitel dan disekresi oleh reseptor Ig polimer (pIgR) yang disebut juga komponen membran sekretori. ${ }^{14}$

Polimer IgA diproduksi oleh sel plasma di lamina propria mukosa mulut. Polimer IgA mengikat reseptor imunoglobulin pada permukaan sel epitel, kemudian dengan endositosis reseptor IgA kompleks melewati kompartemen selular sebelum dikeluarkan ke permukaan sel epitel. Kemudian terjadi proteolisis reseptor dan molekul IgA dimer serta komponen sekretori bebas untuk menyebar keseluruh mukosa termasuk ke dalam saliva. ${ }^{14,16}$

SIgA berperan dalam memblokade reseptor epitel (misalnya dengan mengikat ligan mereka pada bakteri patogen), yang menghambat perlekatan bakteri patogen pada sel epitel. Selain itu suatu proses aglu- 
tinasi antigen polivalen atau ikatan patogen dengan antibodi, akan menjebak bakteri patogen dalam lapisan lendir. Rantai oligosakarida dari komponen SIgA juga dapat berikatan dengan lapisan lendir yang terdapat dipermukaan sel epitel, sehingga bakteri patogen tidak bisa melekat pada permukaan epitel mulut. ${ }^{15,17,18}$

\section{PEMBAHASAN}

Sifat antimikroba cairan tubuh eksternal sudah lama diketahui dan digunakan sebagai aplikasi topikal seperti saliva, kolostrum atau urin sebagai obat atau profilaksi. Banyak faktor pertahanan bawaan dengan aktivitas antimikroba seperti lisozim dan laktoferin, pada sekresi eksokrin dapat berfungsi sebagai barier membran mukosa, disamping sifat perisai fisik epitel dan musin. Semua komponen ini merupakan kekebalan bawaan yang bekerjasama erat dengan imunitas humoral adaptif yang dimediasi oleh antibodi. Disamping fungsi SIgA sebagai barier dengan memperkuat epitel mukosa mulut, SIgA akan berikatan dengan epitop dari bagian antigen I/II S. mutans, sehingga bakteri tidak dapat berikatan dengan pelikel saliva, maka S.mutans tidak bisa berkolonisasi pada permukaan gigi. Penghambatan pembentukan matriks plak dan penghambatan inisiasi agregasi bakteri dapat mencegah kolonisasi awal bakteri, sehingga kolonisasi akhir juga tidak akan terbentuk. Oleh karena itu hal ini dapat menghalangi pembentukan biofilm (plak) pada permukaan gigi yang disebabkan oleh S.mutans. ${ }^{4-6,}{ }^{15}$ Untuk mendukung proses ini, menjaga kuantitas dan kualitas dari SIgA di rongga mulut adalah sangat penting. ${ }^{19}$ Beberapa hal berikut mungkin dapat kita lakukan antara lain yaitu: meperhatikan asupan gizi yang dapat meningkatkan jumlah SIgA di ronnga mulut, seperti mengkomsumsi suplemen probiotik dan makanan sehat lainnya, serta menghindari atau mengobati penyakit-penyakit yang dapat menurunkan daya tahan tubuh secara keseluruhan. ${ }^{6,17}$

Dalam usaha pencegahan dini kerusakan gigi susu pada anak-anak, asupan IgA melalui ASI juga dapat menjadi pertimbangan, terutama bagi ibu-ibu menyusui yang memberikan ASI ekslusif. Disamping itu penting juga untuk memperhatikan pola dan cara menggosok gigi yang benar dalam upaya pencegahan karies gigi. Dapat disimpulkan, S. mutans merupakan salah satu bakteri patogen penyebab utama karies gigi. Sistem imun di rongga mulut yang diperankan oleh sekretori IgA (SIgA), dapat berikatan secara spesifik dengan epitop dari antigen I/II S. mutans, sehingga bakteri tidak bisa berikatan dengan pelikel saliva dan S. mutans tidak akan berkolonisasi pada permukaan gigi.

\section{Daftar Pustaka}

1. Badan Penelitian dan Pengembangan Kesehatan Kementrian Kesehatan RI. Riset Kesehatan Dasar. Jakarta, 2013; 110-19.

2. Bowen WH, Koo H. Biology of Streptococcus mutans-derived glucosyltransferases: Role in extracellular matrix formation of cariogenic biofilms. Caries Res 2011;45(1):69-86.

3. Yuliati A. Identifikasi epitop dari Streptococcus mutans terhadap sekretori Imunoglobulin A saliva ( The identification of Streptococcus mutans epitopes to secretory). Majalah Ked Gigi (Dent J) 2005; 38(3): 103-7.

4. Ahn SJ, Wen ZT, Brady J, Burne R. Characteristics of biofilm formation by Streptococcus mutans in the presence of saliva. Infect Immun 2008; 76(9): 4259-68.

5. Esberg A, Löfgren-Burström A, Öhman U, Strömberg N. Host and bacterial phenotype variation in adhesion of Streptococcus mutans to matched human hosts. Infect Immun 2012; 80(11): 3869-79.

6. Krzyściak W, Jurczak A, Kościelniak D, Bystrowska B, Skalniak A. The virulence of Streptococcus mutans and the ability to form biofilms. Eur J Clin Microbiol Infect Dis 2014; 33(4): 499-515.

7. Huang L, Xu Q, Liu C, Fan M, Li Y. Anti-caries DNA vaccine-induced secretory immunoglobulin A antibodies inhibit formation of Streptococcus mutans biofilms in vitro. Acta Pharmacol Sin. Nature Publishing Group, 2013; 34(2): 239-46.

8. Nogueira RD, King WF, Gunda G, Culshaw S, Taubman M a., Mattos-Graner RO, et al. Streptococcus mutans infection induces Salivary antibody to virulence proteins and associated functional domains. Infect Immun 2008; 76(8): 360613.

9. McCarlie VW, Jr JKH, Blum JS, González- C, Chin JR, Eckert GJ, et al. Total IgA and IgA reactivity to antigen I/II epitopes in HLA-DRB*04 positive subjects. J Immunol 2013; 3(3): 82-92.

10. Lemos JA, Quivey RG, Koo H, Abranches J. Streptococcus mutans: A new gram-positive paradigm? Microbiol 2013; 159: 436-45.

11. Shinozaki-Kuwahara N, Hashizume-Takizawa T, Hirasawa M, Takada K. A feasible enzyme-linked immunosorbent assay system using monoclonal and polyclonal antibodies against glucosyltransferase-B from Streptococcus mutans. Hybridoma 2012; 31(3): 176-9.

12. Matsui R, Cvitkovitch D. Acid tolerance mechanisms utilized by Streptococcus mutans. Futur Microbiol 2010;5(3):403-17.

13. Kamiya RU, Taiete T, Gonçalves RB. Mutacins of Streptococcus mutans. Brazilian J Microbiol 2011; 42(4): 1248-58.

14. Brandtzaeg P. Secretory IgA: Designed for antimicrobial defense. Front Immunol 2013; 4: 1-17.

15. Brandtzaeg P. Secretory immunity with special 
reference to the oral cavity. J Oral Microbiol 2013; 5(2013): 1-24.

16. Hamuro K, Kotani Y, Toba M, Kakumoto K, Kohda N. Comparison of Salivary IgA Secretion Rate Collected by the Aspiration Method and Swab Method. Biosci Microbiota, Food Heal 2013; 32(3):107-12.

17. Ericson D, Hamberg K, Bratthall G, SinkiewiczEnggren G, Ljunggren L. Salivary IgA response to probiotic bacteria and Streptococcus mutans after
18. the use of chewing gum containing Lactobacillus reuteri. Pathog Dis 2013; 68(3): 82-7.

19. Gibbins HL, Proctor GB, Yakubov GE, Wilson S, Carpenter GH. SIgA Binding to Mucosal Surfaces Is Mediated by Mucin-Mucin Interactions. PLoS One J Pone 2015; 10(3): 1-4.

20. Ito T, Maeda T, Senpuku H. Roles of salivary components in Streptococcus mutans colonization in a new animal model using NOD/ SCID.e2f1 -/mice. PLoS One J Pone. 2012; 7(2): 1-9. 